\title{
Digital Preservation of Cultural Heritage: Terengganu Brassware Craft Knowledge Base
}

\author{
Wan Malini Wan Isa ${ }^{1}$, Nor Azan Mat Zin ${ }^{2 *}$, Fadhilah Rosdi ${ }^{3}$, Hafiz Mohd Sarim ${ }^{4}$ \\ Faculty of Information Science and Technology, University Kebangsaan Malaysia, Malaysia 1, 2,3,4 \\ Faculty of Informatics and Computing, University Sultan Zainal Abidin, Malaysia ${ }^{1}$
}

\begin{abstract}
Early exposure to cultural heritage is necessary to preserve it from extinction. One form of cultural heritage that is now on the brink of extinction is the Terengganu brassware craft. Current young generations are mostly not interested in this heritage. Furthermore, intangible heritage in the form of knowledge and skills are only stored in the memory of the practitioners. Lack of documentation has led to the sole reliance on practitioners such that the knowledge is lost upon their demise. Hence, intangible heritage knowledge has to be acquired and stored in a knowledge base system to keep them in a systematic and permanent form. Manipulating and transferring the knowledge and skills will also ensure the continuity of this heritage, and ensure it can be accessed by future generations. This paper discusses the development of the knowledge base of Terengganu Brassware Craft as a digital preservation of cultural heritage. Knowledge acquisition was carried out using interview and observation techniques. Then, the knowledge is represented using ontology. This knowledge, in digital form, can be manipulated and disseminated to the community to ensure the continuity of the knowledge.
\end{abstract}

Keywords-Cultural heritage; digital preservation; intangible cultural heritage; knowledge acquisition; knowledge base; knowledge representation; ontology

\section{INTRODUCTION}

Cultural heritage is a treasure that has been or is owned by a person or a group of societies or people who collectively share responsibilities for protection and retention. Cultural heritage can be divided into tangible and intangible cultural heritage. Tangible cultural heritage is something that can be perceived and held, either static or mobile. Examples include monuments, buildings, and textiles. Intangible cultural heritage, on the other hand, refers to knowledge and expertise that are interpreted through oral tradition, customary values, and culture, language, and writing. Examples of intangible cultural heritage are festive events, rituals and beliefs, performing arts, visual arts, and traditional medical art. Terengganu brassware craftsmanship is an example of intangible heritage that can be categorized under traditional craftsmanship.

Recent technological developments enable the digital preservation of knowledge. One of the goals of digital preservation is to gather, refine, maintain, and share cultural resources that can subsequently be used by scholars, members of the community, and younger generations [1]. The use of current technology such as a knowledge base has improved the knowledge management of cultural heritage, particularly

\footnotetext{
* Corresponding Author

The research is funding by Universiti Kebangsaan Malaysia under the Grand Challenge Fund (DCP-2017-007/2).
}

intangible heritage, to be more efficiently and effectively managed. Furthermore, the development of a knowledge base has enabled the storing of this knowledge in a digital and systematic form to preserve it and ensure the sustainability of this cultural heritage in the future. The stored knowledge can then be used to develop applications such as websites, games or mobile applications for the dissemination of intangible cultural heritage.

Currently, cultural heritage, especially intangible heritage such as Terengganu brassware craft, is dying out because most of the younger generation is no longer interested in learning and preserving the heritage. Lack of young people becoming apprentices contributes to the slow extinction and maybe eventual loss of this heritage to the society, unless effort to preserve the knowledge is carried out. Moreover, according to previous work [2], the traditional method of transferring intangible heritage knowledge has been done through personal and verbal information exchange, specifically by imitating, observing and listening to the master craftsman. This traditional way of transferring knowledge lead to heritage knowledge not properly preserved and the absence of documentation cause sole reliance on the practitioners' knowledge, thus causing the knowledge to be forgotten and lost with the death of individual practitioners. Therefore, some preservation efforts are needed to ensure the continuity of the cultural legacy.

This paper discusses the development of a knowledge base for Terengganu brassware craft cultural heritage as a digital preservation effort for dying craft. The remaining of the paper is organized as follows: Section II discusses the background and related works on cultural heritage and their preservation; Section III describes the method used for this study; Section IV presents the results and discussion; and Section $\mathrm{V}$ presents the conclusion.

\section{BACKGROUND AND RELATED WORK}

\section{A. Terengganu Brassware Craft}

Terengganu is a State located on the East Coast of Malaysia. There are various types of well-known cultural heritage in Terengganu such as batik, wicker, and woodcarving. One famous heritage in the State is the brassware craft founded 300 years ago. In the past, the production of brassware craft was very active in Kampung Ladang and Kampung Tanjung, Kuala Terengganu. The brassware craft produced by the Terengganu craftsmen is a Peninsula Malay art that has a high-quality artistic identity and shape [3]. Study 
from [4] states that the symbols and identities highlighted in the brassware craft have artistic elements and aesthetic values that reflect the identity and culture of the Malay community.

Although the craft was popular in the local community in the past, presently, the brassware craft industry is in a critical phase, as the market and production of brassware-based craft products have decreased. A recent study stated that this craft is almost extinct due to the lack of sustainability, skills, and interests of the younger generation, and limited modern technology applications [5]. Therefore, this craft should be preserved and maintained to ensure its sustainability for future generations.

\section{B. Digital Preservation of Cultural Heritage}

Cultural heritage encompasses the whole environment that reflects the activities and successes of the past that cannot be interchanged [6]. This makes the preservation of cultural heritage very important and shows that efforts need to be taken to ensure its sustainability for future generations. According to Kamus Dewan, preservation means maintaining, defending, and caring while another study [7] defined it as an action that preserves cultural heritage objects and historical objects. Besides that, another definition of preservation from [8] is an act or process of taking action to defend the existing form, integrity, and material of a building or structure and the protective plant of a site.

One study [9] listed four key reasons for cultural heritage preservation, which are, cultural memory, convenient proximity, environmental diversity, and economic gain. The importance of cultural heritage as a cultural memorial is that the preservation is able to maintain a historical material in physical form and to transfer valuable knowledge and skills from the past generations to the present and future generations. As convenient proximity, preservation can support interaction among the environment, people, and community activities. Meanwhile, through the diversity of the environment owing to the different or similar identities of the local community, the preservation of cultural heritage will ensure that domestic artifacts and craftsmen are preserved amidst urban expansion. Lastly, preservation can benefit the community in terms of economic growth, namely, the cost of building new buildings and turning them into tourist attraction spots can be saved.

Digital preservation is one of the methods to keep the history of a country alive. Technological advancement has led to digital preservation being more widely used in libraries, museums, and information centers. Digital preservation can be defined as a proper architecture that consists of packages that are commonly implemented by archivists to ensure that the information is always available, as well as to ensure its usability and interpretability [10]. Digital preservation does not only preserve culture and legacy; it also enables easy documentation of the materials, which can be used as an educational reference for the future generation [11]. Furthermore, digitalization offers a platform for existing users and the upcoming generation to access cultural information, so that they can learn, comprehend, and even create digital resources using the Internet [1].
There are various methods of digital preservation that can be carried out such as three-dimensional modeling [10], [12], virtual reality [13], [14], augmented reality [15], and so on. In addition, a knowledge base is also an effective method for digital preservation. A knowledge base is defined as a collection of knowledge about the world that is processed by computers [16]. Besides, it also acts as a centralized warehouse for information or as a database on a particular subject [17]. A knowledge base is an essential element in knowledge-based systems for optimizing information gathering, organizing information, and perusing certain information. Since cultural heritage has a lot of knowledge to be preserved, especially intangible cultural heritage, the use of a knowledge base is significant as a medium of digital preservation and documentation.

\section{METHOD}

This section would discuss the activities involved in developing the knowledge base for Terengganu brassware craft such as knowledge acquisition and knowledge representation. Fig. 1 shows the process flows for developing a knowledge base for Terengganu brassware craft. The development of the Terengganu brassware craft knowledge base consists of three main activities- knowledge acquisition, analysis and knowledge representation. The first activity is the knowledge acquisition which involves the process of gathering and obtaining knowledge from the domain experts using interview and observation techniques. Next, the knowledge obtained from the previous activity is analyzed by coding, clustering and identifying the knowledge to be used for subsequent activities. The third activity is the knowledge representation process whereby an ontology was developed and then stored in a knowledge base. This knowledge base is developed in Malay language, since the knowledge to be preserved is a Malay cultural heritage. The description of each activity is described in the next section.

\section{A. Knowledge Acquisition}

Knowledge acquisition is a process of obtaining knowledge from sources such as experts, books, documents, or computers [18]. The knowledge gained includes specific knowledge of a problem domain or problem-solving in general or metaknowledge, or information about how experts use their knowledge to solve problems. Author [19] mentions there are several techniques used in the process of acquiring knowledge such as manual methods (e.g. interview, surveys, observation), automated tools (e.g. traditional machine learning techniques), interactive computer-based tools, or combinations of these.

In this study, the knowledge acquisition part involved exploring and acquiring knowledge from Terengganu brassware craft experts about this valuable heritage. Knowledge about craftsmanship is a tacit knowledge, which is shared through socialization (tacit to tacit) from generation to generation. Tacit knowledge is a knowledge that is based on an individual's experience, is deeply embedded, hard to express and explain, not yet articulated, and is equal to the practical know-how knowledge [1]. 


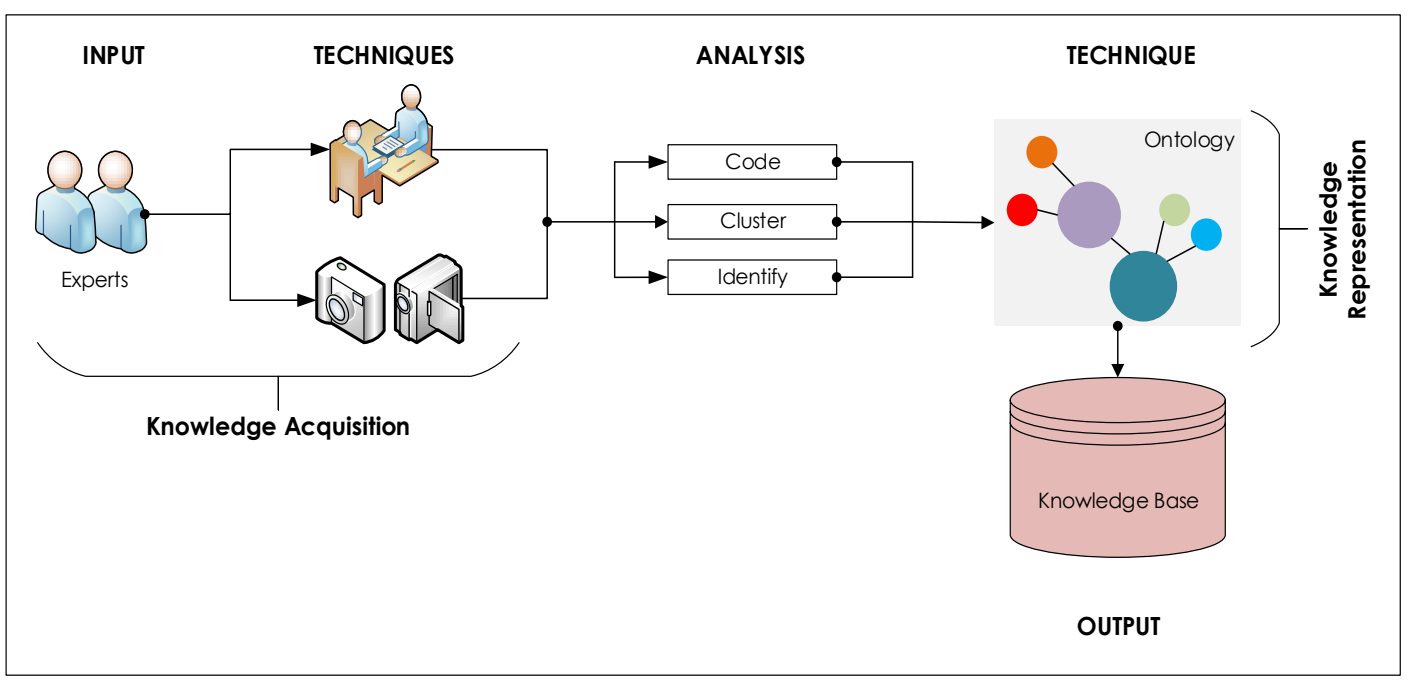

Fig. 1. Overview of Processes in Developing the Knowledge base for Terengganu Brassware Craft.

Since the knowledge investigated is tacit, interview and observation methods were used to acquire this knowledge from the experts i.e. the brassware craftsmen. These methods were employed to extract the knowledge because the craftsmen usually keep this knowledge in their memory and pass them down through personal exchanges and oral tradition. For this study, three craftsmen were selected for the interview, as they are considered experts by virtue of being involved in the brassware craft industry for more than 10 years. In addition, interviews were also conducted with Terengganu Museum officers and a Terengganu Branch officer from Perbadanan Kemajuan Kraftangan Malaysia, to get more information on the brassware artifacts and products.

Before the fieldwork was carried out, an extensive review of the literature was performed to explore the basic knowledge of brassware craft and to help frame the interview questions. An extensive review was done by obtaining information from books, journals, and online sources. While for the interview, a semi-structured interview approach was selected as the means for knowledge gathering. This interview format allowed for specific questions and topics to be addressed while offering the respondents an opportunity to give additional feedback and elaborate further on any aspect of their experience they considered relevant to this study [20]. Semi-structured interview questions were developed, consisting of 20 questions that can be categorized into three main categories: a) history of brassware, b) brassware artifacts or products, and c) brassware producing process.

Apart from that, an observation method was carried out after the interview sessions to obtain a better understanding of the process of making brassware craft. The outputs from the interview were transcribed into textual format while the findings from the observations were recorded in the form of images and videos. The data were then transferred to a computer. These data from the knowledge acquisition activities were then analyzed following several steps such as coding and clustering. Then, the important knowledge was identified and extracted for the implementation of knowledge representation activities.

\section{B. Knowledge Representation}

Knowledge representation is a process of understanding, designing, and implementing ways to represent the information acquired so that it can be used by the computer [21]. It is to find the mapping between knowledge and representation and then choosing a suitable form to express knowledge, that is to make the facts, rules, concepts of the world coded into a suitable data structure, then representing them in an acceptable form using the computer [22].

In this study, knowledge was represented in the form of ontology because ontology provides a clear organization of specialized knowledge and multidimensional representation. Ontology also permits people or software agents to share a common understanding of the information structure and enables the reuse of the developed domain knowledge. Besides, study from [1] states that ontology is one of the alternatives used to represent the domain of knowledge, where this method helps us to perform the semantic modeling of concepts, and to represent axioms in ontology in logic languages.

There is a well-known ontology for the cultural heritage domain, namely CIDOC CRM. The CIDOC CRM allows integration, mediation, and interchange of information of diverse cultural heritage and their association with the digital library and archive data. It is used to summarize various schemata (80 classes and 130 relationships) under different museum fields as well as to enhance the knowledge semantic from distributed databases of cultural heritage [23]-[25]. Nevertheless, several studies [26], [27] have revealed that the CIDOC CRM approach was considered too focused on museums with only less than $5 \%$ of the ideas of CIDOC CRM actually being utilized by the museums.

Ontology development can be carried out either by reusing and integrating with existing ontology or developing from scratch [28], [29]. However, some researchers claim that it is better to develop a new ontology from scratch rather than correcting the existing ontology, especially in terms of costing [30]. For this study, the ontology for brassware craft was developed from scratch since there is no existing ontology that 
is suitable for the traditional craftsmanship domain. Ontology Development 101 [31] was selected as a method to develop the brassware craft ontology. This method consists of five phases, namely specification, integration, conceptualization, implementation, and evaluation, as shown in Fig. 2.

The first phase is the specification phase in which the domain, purpose, and scope of the ontology were defined. The domain for this ontology is an intangible cultural heritage that focuses on brassware craft while the purpose of the ontology development is to model the brassware craft knowledge base. The integration phase is not relevant in this development, as this ontology is not integrated with other ontologies. Next is the conceptualization phase where all possible terms and properties related to the terms of the domain were listed down. Then, class, properties, and instances were defined based on the terms.

In the implementation phase, a software, i.e. Protégé version 5.2 was selected as the ontology engineering environment and the Web Ontology Language (OWL) was set as the ontology language. The final phase is the evaluation phase that was carried out to evaluate and debug the performance of the ontology model. SPARQL query was used to verify the accuracy and correctness of the knowledge representation.

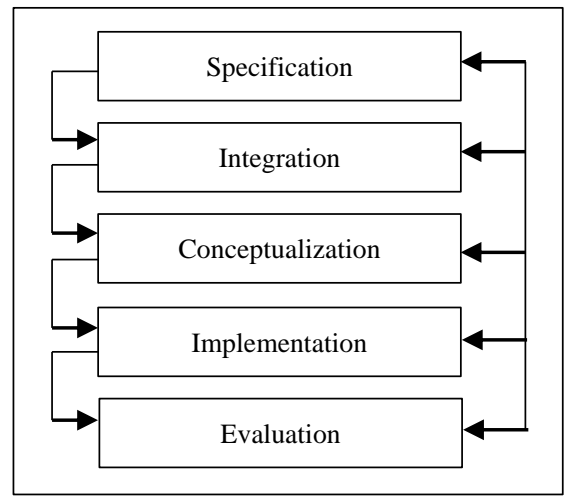

Fig. 2. Ontology Development 101 [31].

\section{RESULTS AND DISCUSSION}

This section discusses the results from the knowledge acquisition and knowledge representation activities.

\section{A. Knowledge Acquisition Result}

Based on the interviews, it was found that there are different opinions regarding the origin of the Terengganu brassware industry; it could have originated from China, India or Patani, Thailand. In addition, there is no written evidence as to when the industry began in Terengganu, but based on the estimation of the industry, it has been operating in Terengganu for more than 300 years. Respondents also stated that the past glory of the craft industry in Terengganu reached its peak when the Sultan's palace court recognized and encouraged the people to study the art.

Knowledge of the artifacts was obtained from Muzium Terengganu while knowledge about the products was obtained from the craftsmen and Perbadanan Kemajuan Kraftangan Malaysia, Terengganu Branch. The knowledge acquired includes the artifacts or product names, the function of each product, the motifs or design, and the manufacturing year and size. Table I shows examples of brassware artifact knowledge.

Furthermore, the most important knowledge gained was the traditional method of producing brassware craft including the materials and equipment used, which is known as the lost wax brass casting technique. From the interviews and observations, it can be concluded that there are 11 major processes involved in the production of brassware craft, as shown in Fig. 3. Besides that, knowledge was also acquired on the main materials used, which include the metal mixture consisting of copper, zinc, tin, nickel, aluminum, and other materials used such as wax, clay, sand, and others. The types of equipment used were crucibles, ground furnaces, grinder machines, and many others.

\section{B. Knowledge Representation Result}

The result of knowledge representation from the previous activities was presented in the form of a list of all the terms and properties related to the terms as, well as the examples of the terms, such as the name of the artifacts, the list of motifs, the usage, the materials, and the equipment. Based on these terms, the concepts were identified; however, the concepts alone were not enough to provide comprehensive information. Therefore, the properties of the concepts were defined, for example, the concepts of the artifacts and their properties such as name, motifs, and usage was further defined. The instances for the concepts were also identified based on the terms. Ontology was also applied to the process of brassware production, broken down into properties such as sub-processes, materials, and equipment. The representation of knowledge was stored in the knowledge base. Table II shows the basic terms of the concepts and properties of brassware ontology. Meanwhile, Table III lists the relationship between the concepts and the properties.

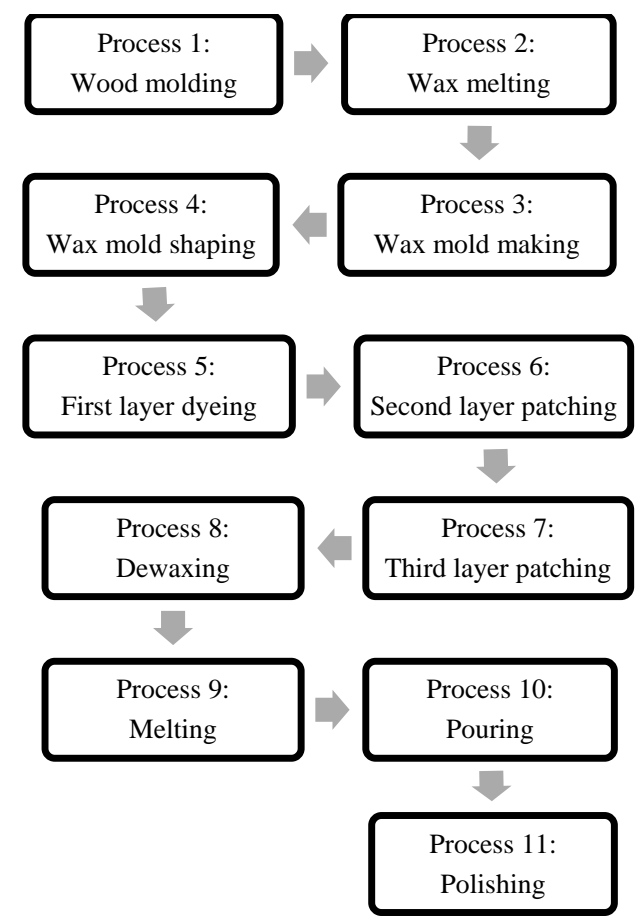

Fig. 3. The main Process in Producing Terengganu Brassware Craft. 
TABLE I. BRASSWARE ARTIFACT KNOWLEDGE

\begin{tabular}{|c|c|c|c|c|}
\hline Name & Function & Motifs & Size & $\begin{array}{l}\text { Year of } \\
\text { manufactur } \\
\text { e }\end{array}$ \\
\hline $\begin{array}{l}\text { Rectangular } \\
\text { betel leaf } \\
\text { holder } \\
\text { (Tepak } \\
\text { sirih biasa } \\
4 \text { segi) }\end{array}$ & $\begin{array}{l}\text { Used as a place } \\
\text { for storing gobek, } \\
\text { betel leaf, } \\
\text { gambier, betel } \\
\text { nut, and other } \\
\text { requirements } \\
\text { while eating betel }\end{array}$ & $\begin{array}{l}\text { Geome } \\
\text { try }\end{array}$ & $\begin{array}{l}\text { Length: } 20.2 \\
\text { cm } \\
\text { Width: } 10.2 \\
\text { cm } \\
\text { Height: } 5.0 \\
\text { cm }\end{array}$ & $\begin{array}{l}\text { Around the } \\
90 \text { s }\end{array}$ \\
\hline $\begin{array}{l}\text { Brassware } \\
\text { pitch } \\
\text { (Kendi } \\
\text { tembaga) }\end{array}$ & $\begin{array}{l}\text { Used as a tool for } \\
\text { storing water for } \\
\text { drinking } \\
\text { purposes, } \\
\text { washing hands } \\
\text { and so on }\end{array}$ & Floral & $\begin{array}{l}\text { Length: } 27.0 \\
\text { cm } \\
\text { Width: } 19.5 \\
\text { cm } \\
\text { Height: } 22.4 \\
\text { cm } \\
\text { Weight: } 2.4 \\
\text { kg }\end{array}$ & $\begin{array}{l}\text { Around the } \\
70 \mathrm{~s}\end{array}$ \\
\hline $\begin{array}{l}\text { Brassware } \\
\text { wok (Kuali } \\
\text { Tembaga) }\end{array}$ & $\begin{array}{l}\text { Used as a tool for } \\
\text { cooking dishes } \\
\text { and stirring cakes }\end{array}$ & $\begin{array}{l}\text { Geome } \\
\text { try }\end{array}$ & $\begin{array}{l}\text { Diameter: } 45 \\
\mathrm{~cm} \\
\text { Height: } 21 \mathrm{~cm}\end{array}$ & $\begin{array}{l}\text { Around the } \\
80 \text { s }\end{array}$ \\
\hline
\end{tabular}

Then, the result of the implementation was obtained and illustrated in Fig. 4 and Fig. 5. Fig. 4 shows the visualization part of the Terengganu brassware craft ontology. This ontology has eight main classes which are Artifak, Kategori, Motif, Sejarah, Bahan, Peralatan, Proses and LangkahProses. There are twelve subclasses under the main classes such as Logam and PasirPantai under Bahan class. Instances are created under appropriate class with the relation name has individual, for example, the instance Proses01_Pembentukan_Acuan_Kayu belongs to the Proses class. Object property is used to link instances such as Proses01_Pembentukan_Acuan_Kayu has property hasLangkah; whereby Melarik_kayu and Melicinkan_acuan_kayu are two instances of LangkahProses class.
Fig. 5 shows an excerpt of the OWL representation of brassware ontology in OWL/XML syntax serialization (.owl). Kuali_Tembaga and Tepak_Sirih_Biasa_4_Segi are declared as individual instances. Class LangkahProses is created and has Melarik_kayu as its instance. Object property hasBahan is linked to Melarik_kayu and material Kayu_Cengal. While, data property, Keterangan is linked to the instances Melarik_Kayu with data value such as Acuan kayu diperbuat dari bongkah kayu dan dibentuk dengan melarik kayu tersebut mengikut bentuk yang dikehendaki. Acuan kayu dilarik menggunakan mesin pelarik dan pahat pelarik kayu.

TABLE II. BASIC TERMS OF CONCEPTS AND PROPERTIES FOR TERENGGANU BRASSWARE CRAFT ONTOLOGY

\begin{tabular}{|l|l|}
\hline Concepts & Properties \\
\hline Artifak (Artifact) & - \\
\hline Proses (Process) & hasLangkah \\
\hline LangkahProses (ProcessSteps) & isLangkahOf \\
\hline Bahan (Material) & hasBahan \\
\hline Peralatan (Equipment) & hasPeralatan \\
\hline Kategori (Category) & hasKategori \\
\hline Motif (Motif) & hasMotif \\
\hline Sejarah (History) & - \\
\hline
\end{tabular}

TABLE III. RELATIONSHIP BETWEEN CONCEPTS AND PROPERTIES

\begin{tabular}{|c|c|c|c|}
\hline Concept Name & Instance Name & Property & Value \\
\hline \multirow{2}{*}{$\begin{array}{l}\text { Artifak } \\
\text { (Artifact) }\end{array}$} & \multirow{2}{*}{$\begin{array}{l}\text { Tepak sirih biasa } 4 \\
\text { segi }\end{array}$} & hasMotif & Geometri \\
\hline & & hasKategori & Adat istiadat \\
\hline $\begin{array}{l}\text { Proses } \\
\text { (Process) }\end{array}$ & $\begin{array}{l}\text { Proses1: } \\
\text { Pembentukan Acuan } \\
\text { kayu }\end{array}$ & hasLangkah & Melarik kayu \\
\hline \multirow{2}{*}{$\begin{array}{l}\text { LangkahProses } \\
\text { (ProcessSteps) }\end{array}$} & \multirow{2}{*}{ Melarik kayu } & hasBahan & Kayu seraya \\
\hline & & hasPeralatan & Mesin Pelarik \\
\hline
\end{tabular}

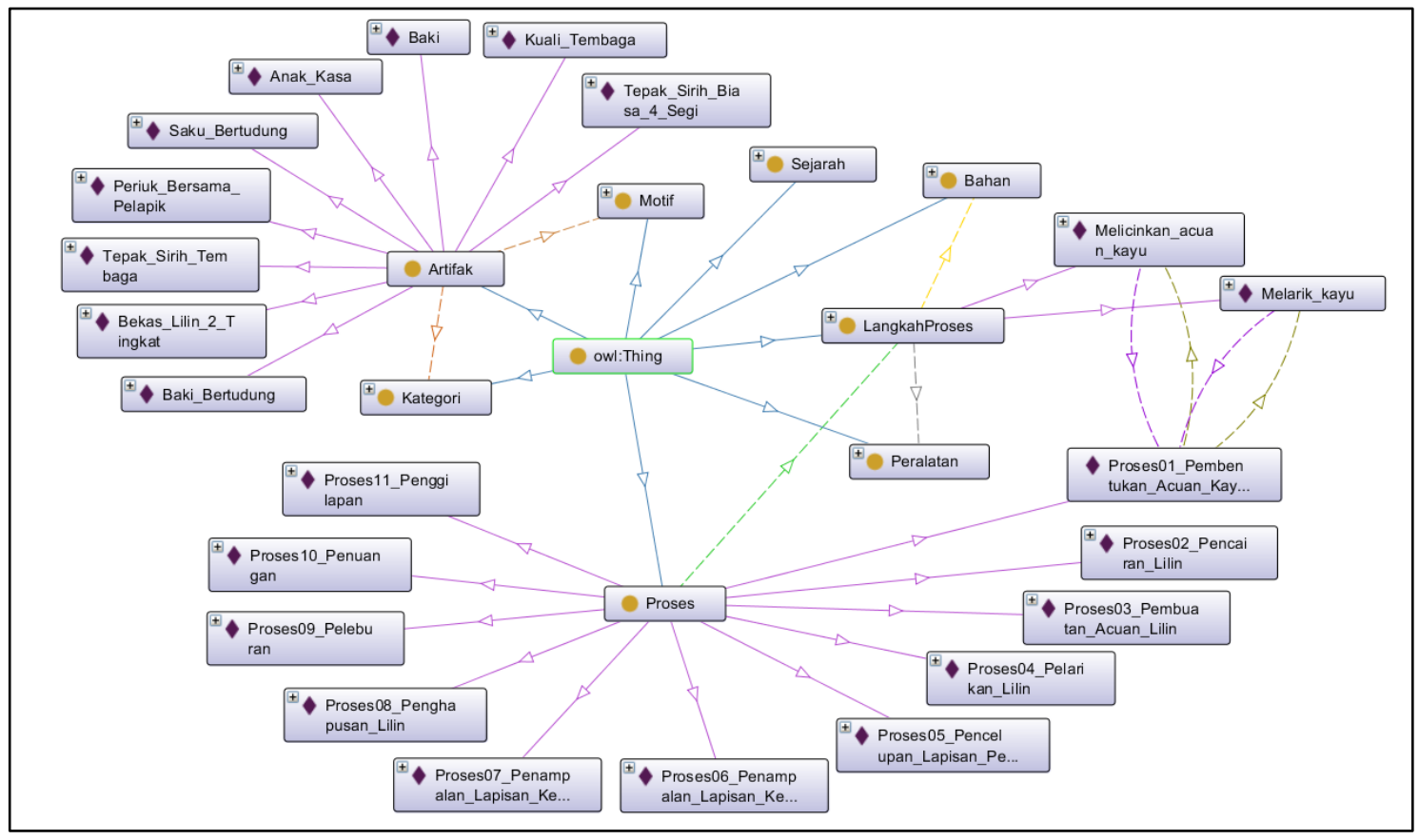

Fig. 4. Visualization Part of the Terengganu Brassware Craft Ontology. 


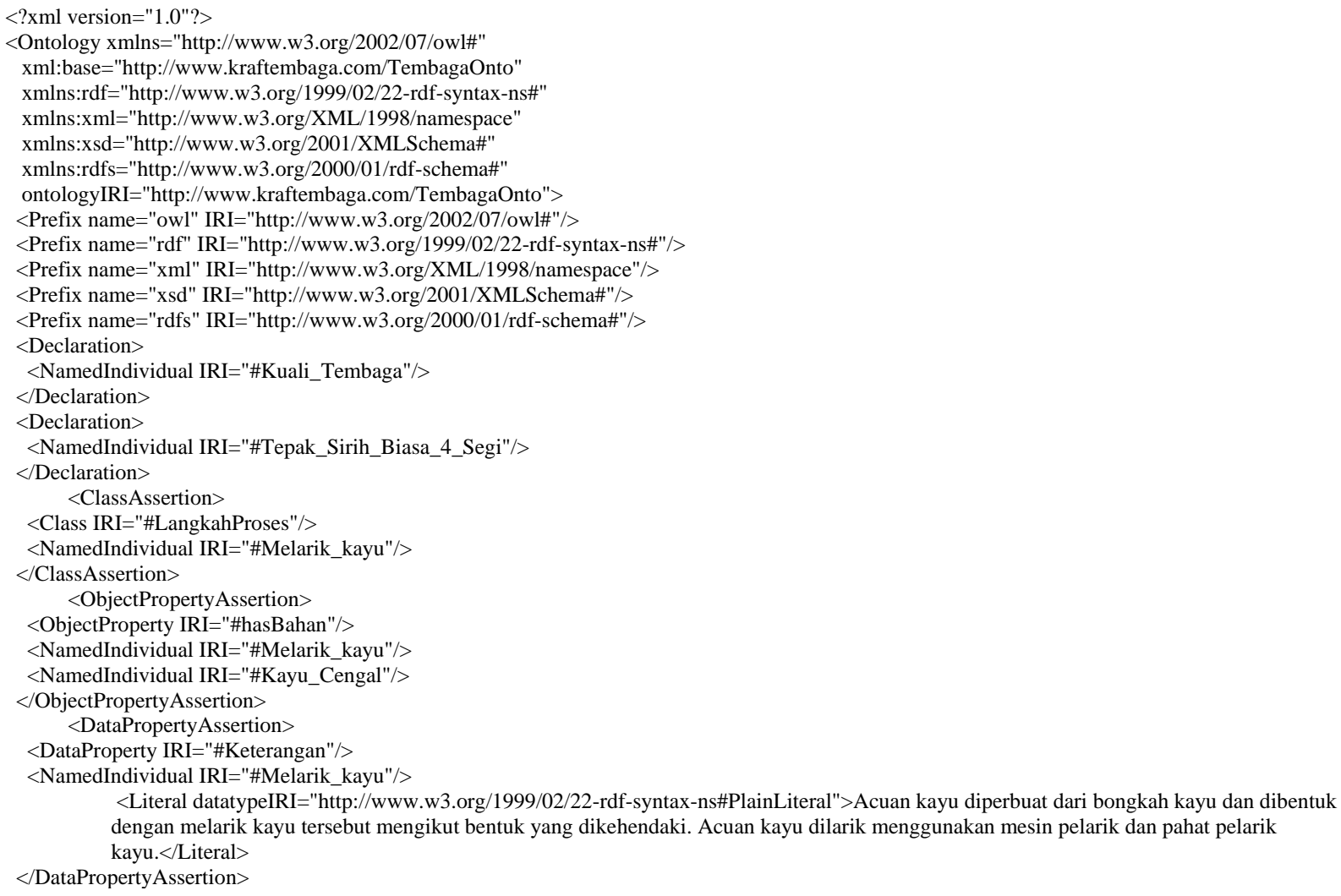

Fig. 5. An Excerpt of the Terengganu Brassware Craft Ontology in OWL Representation.

Evaluation was performed using SPARQL query based on competency questions that were constructed in the first phase. Examples of the evaluation are as follows:

Competency Question 1: What is the process for producing Terengganu brassware craft?

SPARQL query:

SELECT ?Proses

WHERE \{

?class rdfs:subClassOf* krafTem:Proses .

?Proses rdf:type ?class .

\} ORDER BY ?Proses

Answer:

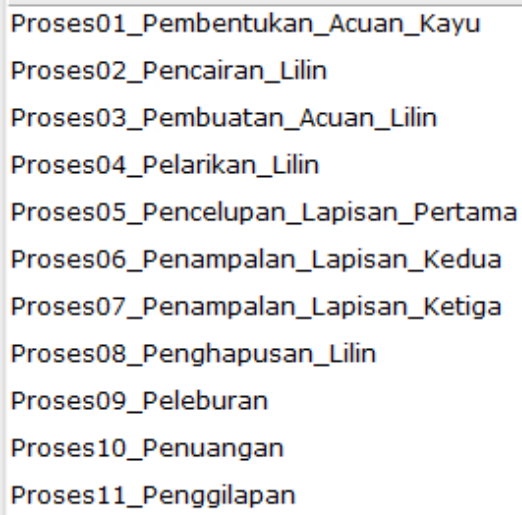

Competency Question 2: What are the steps involved in every process?

SPARQL query:

SELECT ?Proses ?NoLangkah ?Langkah

WHERE \{

?Proses krafTem:hasLangkah ?Langkah .

?Langkah krafTem:NoLangkahProses ?NoLangkah . \} ORDER BY ?Proses ?NoLangkah

Answer:

\begin{tabular}{|c|c|c|}
\hline Proses & Nolanglah & Langlah \\
\hline 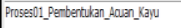 & 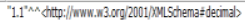 & Melank_kayu \\
\hline 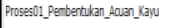 & 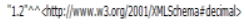 & Melónkan_auan_Layu \\
\hline Proses020_pencaran_Lin & 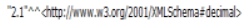 & Mencampurkan_fin__an_danar \\
\hline Prossos 02 Pencaran_Lin & 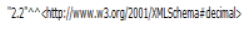 & Menassk_lin \\
\hline 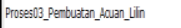 & 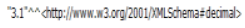 & Membasshkra__auan_layu \\
\hline 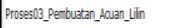 & 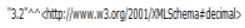 & Mencedup_auan_layu_dam_ifin_panas \\
\hline Proses:03_partustan_tavan_Lín & 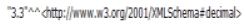 & Mencelup__aun__IIn_dalam_ar \\
\hline Prosses04_Pegarkan_Lin & 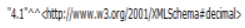 & Melani_zavan_IIn \\
\hline Proseses4_Padarkan_Lin & 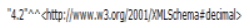 & Menamygakan_ausn_lin \\
\hline Proseses___farkikn_Lín & 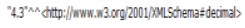 & Merendam_aruen_lin_dalam__air \\
\hline Proses05__Pencelipan_Lapisan_Pestana & 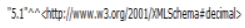 & Membanan__banuhahan_pestama \\
\hline 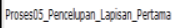 & 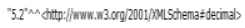 & 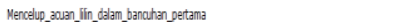 \\
\hline Proses005_Pexcelpan_Lajisan_Patrana & 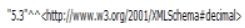 & Mengeringlicn_zavan__apisan_petama \\
\hline Prosese06_Penarpalan_Lapisan_Kedua & 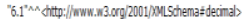 & Menbanach_banahanan_kedua \\
\hline Prosese0__Penarnadan_zapisn_Kedua & 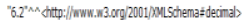 & Menampal__aur__engan__bamahana__kedua \\
\hline Proses06_Penampalan_Lapisan_Kedua & 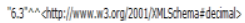 & Mengeningka__aun__apisan_kedua \\
\hline
\end{tabular}

\section{CONCLUSION}

In this paper, knowledge acquisition and representation for the development of a knowledge base for Terengganu brassware craft were discussed. The knowledge acquisition activities involved interviews with brassware experts and 
observation. Meanwhile, ontology was selected as the knowledge representation method since it can represent knowledge for a specific domain. The development of this knowledge base was a significant effort towards the digital preservation of cultural heritage. This study focuses on the development of a knowledge base for intangible cultural heritage of the process of producing Terengganu brassware craft and tangible cultural heritage of artifacts such as design motif and category. Future studies can explore other similar intangible heritage knowledge, besides expanding this knowledge base.

Future works will involve the validation of this knowledge in the knowledge base with a domain expert. This validation is important to verify the knowledge of the brassware craft before it can be applied to other applications such as semantic search or games to disseminate the knowledge to the young generations and thus increase awareness of the preservation and conservation of cultural heritage.

\section{ACKNOWLEDGMENT}

The author would like to acknowledge Universiti Kebangsaan Malaysia for funding this research under the Grand Challenge Fund (DCP-2017-007/2).We also thank the Skim Latihan Akademik (SLAB)/ Skim Latihan Akademik IPTA (SLAI), Ministry of Education Malaysia and Ahmad Zaidi Abd. Wahab from The Society of Terengganu Brassware Entrepreneurs (TEMAGA).

\section{REFERENCES}

[1] Pramartha and J. G. Davis, "Digital preservation of cultural heritage: Balinese Kulkul artefact and practices," Lect. Notes Comput. Sci. (including Subser. Lect. Notes Artif. Intell. Lect. Notes Bioinformatics), vol. 10058 LNCS, pp. 491-500, 2016.

[2] F. M. Dagnino et al., "Serious Games to Support Learning of Rare 'Intangible' Cultural Expressions," 9th Int. Technol. Educ. Dev. Conf. (INTED 2015), no. March, pp. 7184-7194, 2015.

[3] Syed Ahmad Jamal, Form \& Soul. Kuala Lumpur: Dewan Bahasa dan Pustaka, 1994.

[4] A. B. Sabran et al. Fusion ': Eksplorasi Bentuk Kraf Tembaga Melalui Integrasi Teknologi," vol. 3, pp. 114-126, 2015.

[5] S. A. Mohamad, K. A. A. Abd Rahman, and M. F. A. Abdullah, "Problem Analysis and Challenges of Terengganu Brassware Industry," Teren. Int. Tour. Conf. 2013, vol. 2013, pp. 1-7, 2013.

[6] J. Feilden, B. M., \& Jokilehto, Management guidelines for world cultural heritage sites. Paris: ICCROM, 1993.

[7] H. Kurniawan, A. Salim, H. Suhartanto, and Z. A. Hasibuan, "ECultural Heritage and Natural History Framework: an integrated approach to digital preservation," Int. Conf. Telecommun. Technol. Appl., vol. 5, no. November 2015, pp. 177-182, 2011.

[8] E. L. Howe, B. J., Fleming, D. A., \& Kemp, Houses and Homes: Exploring Their History, Vol 2. Rowman Altamira, 1997.

[9] S. Prompayuk and P. Chairattananon, "Preservation of Cultural Heritage Community: Cases of Thailand and Developed Countries," Procedia Soc. Behav. Sci., vol. 234, pp. 239-243, 2016.

[10] A. Belhi, A. Bouras, and S. Foufou, "Digitization and preservation of cultural heritage: The CEPROQHA approach," 2017 11th Int. Conf. Software, Knowledge, Inf. Manag. Appl., pp. 1-7, 2017.
[11] M. Z. Idris, N. B. Mustaffa, and S. O. Syed Yusoff, "Preservation of Intangible Cultural Heritage Using Advance Digital Technology: Issues and Challenges.," vol. 16, no. 1 OP-Harmonia: Journal of Arts Research \& Education; 2016, Vol. 16 Issue 1, p1-13, 13p, p. 1, 2016.

[12] H. Shishido, Y. Ito, Y. Kawamura, T. Matsui, A. Morishima, and I. Kitahara, "Proactive preservation of world heritage by crowdsourcing and 3D reconstruction technology," Proc. - 2017 IEEE Int. Conf. Big Data, Big Data 2017, pp. 4426-4428, 2017.

[13] M. G. Abdelmonem, G. Selim, S. Mushatat, and A. Almogren, "Virtual Platforms for Heritage Preservation in the Middle East: the Case of Medieval Cairo"Int.J. Archit. Res ArchNet-IJAR,vol.11,no.3,p.28, 2017.

[14] Y. Yi and E. J. Shutao, "The Application of Virtual Reality Technology to Heritage Conservation in Famagusta's Armenian Church," 2017, pp. 313-323.

[15] L. W. Shang, T. G. Siang, M. H. Bin Zakaria, and M. H. Emran, "Mobile augmented reality applications for heritage preservation in UNESCO world heritage sites through adopting the UTAUT model," AIP Conf. Proc., vol. 1830, 2017.

[16] T. Rebele, F. Suchanek, J. Hoffart, J. Biega, E. Kuzey, and G. Weikum, "YAGO: A Multilingual Knowledge Base from Wikipedia, Wordnet, and Geonames," in ISWC 2016, Part II, LNCS 9982, vol. 9982, 2016, pp. $177-185$.

[17] A. T. Imam, T. Rousan, and S. Aljawarneh, "An expert code generator using rule-based and frames knowledge representation techniques," 2014 5th Int. Conf. Inf. Commun. Syst. ICICS 2014, pp. 1-6, 2014.

[18] Turban, J. E. Aronson, and T.-P. Liang, Knowledge Acquisition , Representation, Reasoning. 2007.

[19] J. H. Boose, "A survey of knowledge acquisition techniques and tools," Knowl. Acquis., vol. 1, no. 1, pp. 3-37, 1989.

[20] A. Louise Barriball, K., While, "Collecting Data using a semi-structured interview: a discussion paper.," J. Adv. Nurs.,vol 19, pp. 328-335, 1994.

[21] S. C. Shapiro, "Knowledge representation." in Encyclopedia of Cognitive Science, John Wiley Sons, Ltd, 2006.

[22] G. Jiang and X. Cheng, "Building Knowledge Base for Consulting System on Agricultural Practical Techniques," pp. 303-307.

[23] G. Tan, T. Hao, and Z. Zhong, "A Knowledge Modeling Framework for Intangible Cultural Heritage Based on Ontology," 2009 Second Int. Symp. Knowl. Acquis. Model., pp. 304-307, 2009.

[24] H. Liu, H. Bao, J. Wu, and J. Feng, "An Information Flow Based Approach To Semantic Integration Of Distributed Digital Museums," no. August, pp. 4430-4437, 2006.

[25] H. Z. Liu, "Global ontology construction for heterogeneous digital museums,” Proc. Sixth Int. Conf. Mach. Learn. Cybern. ICMLC 2007, vol. 7, no. August, pp. 4015-4019, 2007.

[26] M. Doerr, "The Dream of a Global Knowledge Network - A New Approach," vol. 1, no. 1, pp. 1-23, 2008.

[27] R. Brownlow, S. Capuzzi, L. Martins, I. Normann, and A. Poulovassilis, "An Ontological Approach to Creating an Andean Weaving Knowledge Base," vol. 8, no. 2, pp. 1-31, 2015.

[28] M. Cristani and U. Verona, "A Survey on Ontology Creation Methodologies," vol. 1, no. June, pp. 48-68, 2005.

[29] A. Gómez-pérez and M. D. Rojas-amaya, "Ontological Reengineering for Reuse," pp. 139-156, 1999.

[30] H. S. Pinto and J. P. Martins, "Ontologies: How can They be Built?," Knowl. Inf. Syst., vol. 6, no. 4, pp. 441-464, 2004.

[31] N. F. Noy and D. L. McGuinness, "Ontology Development: A Guide to Creating Your First Ontology.” 2001. 